\title{
Marketing an End to War: Constructive Engagement, Community Wellbeing, and Sustainable Peace
}

Clifford J. Shultz

Loyola University Chicago

Follow this and additional works at: https://digitalcommons.uri.edu/mgdr

Part of the Economics Commons, Marketing Commons, Other Business Commons, Political Science Commons, and the Public Affairs, Public Policy and Public Administration Commons

\section{Recommended Citation}

Shultz, Clifford J. (2016) "Marketing an End to War: Constructive Engagement, Community Wellbeing, and Sustainable Peace," Markets, Globalization \& Development Review. Vol. 1: No. 2, Article 2.

DOI: 10.23860/MGDR-2016-01-02-02

Available at: https://digitalcommons.uri.edu/mgdr/vol1/iss2/2

This Article is brought to you for free and open access by DigitalCommons@URI. It has been accepted for inclusion in Markets, Globalization \& Development Review by an authorized editor of DigitalCommons@URI. For more information, please contact digitalcommons-group@uri.edu. 
Marketing an End to War: Constructive Engagement, Community Wellbeing, and Sustainable Peace

\section{Markets, Globalization \& Development Review}
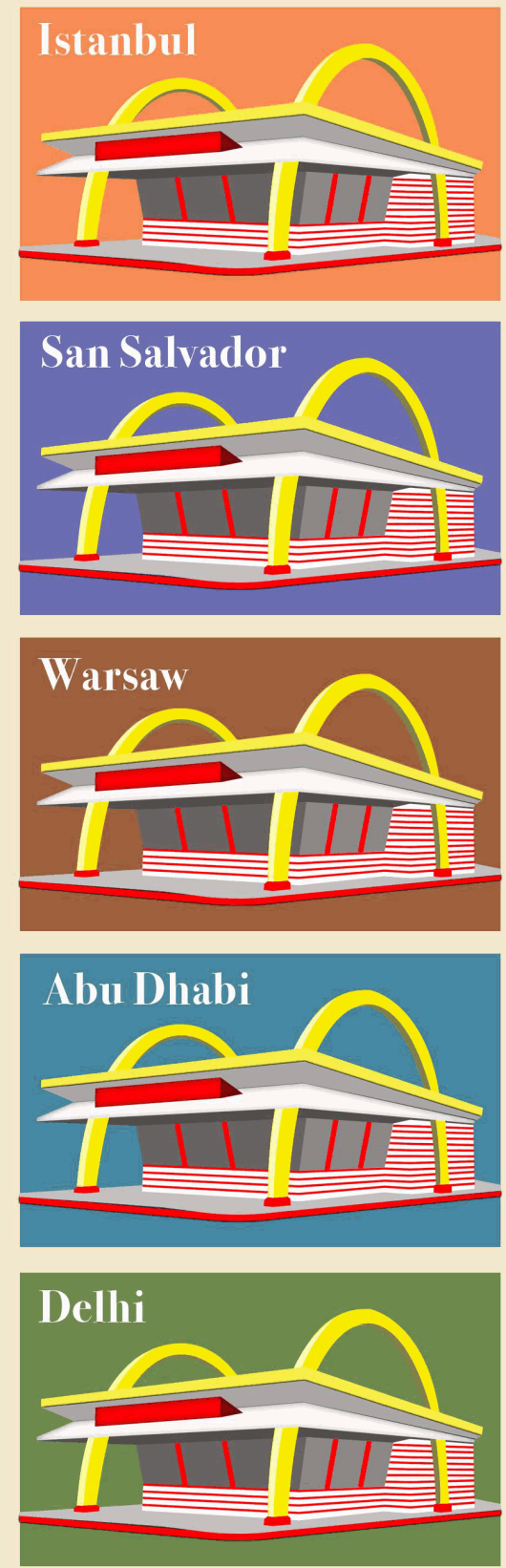
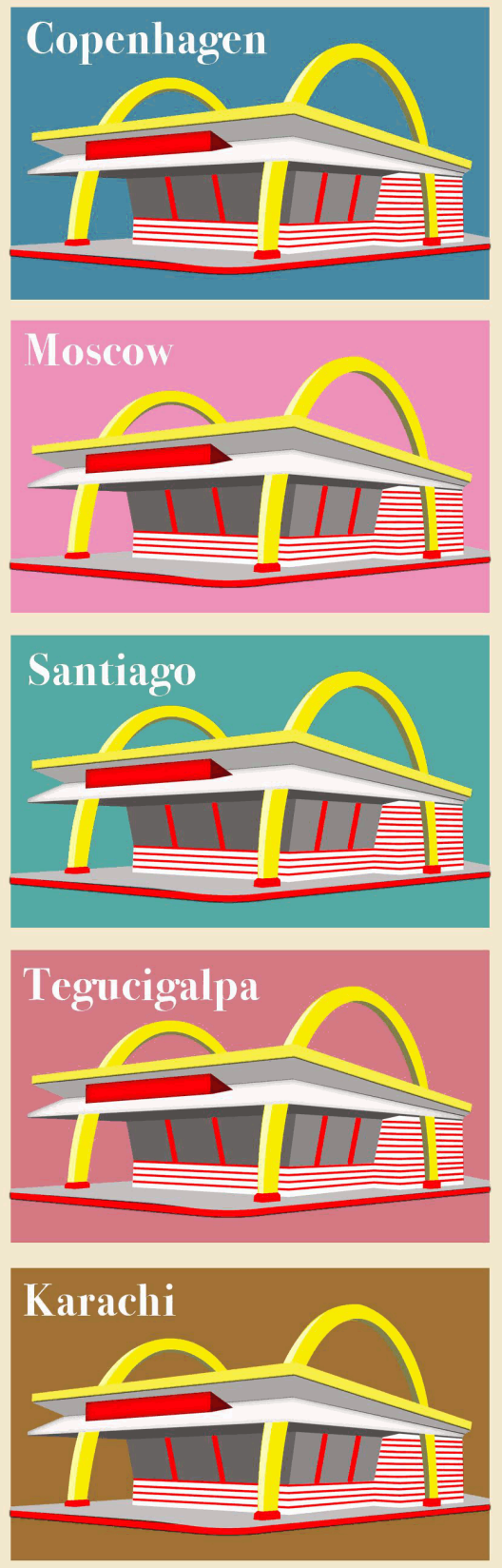
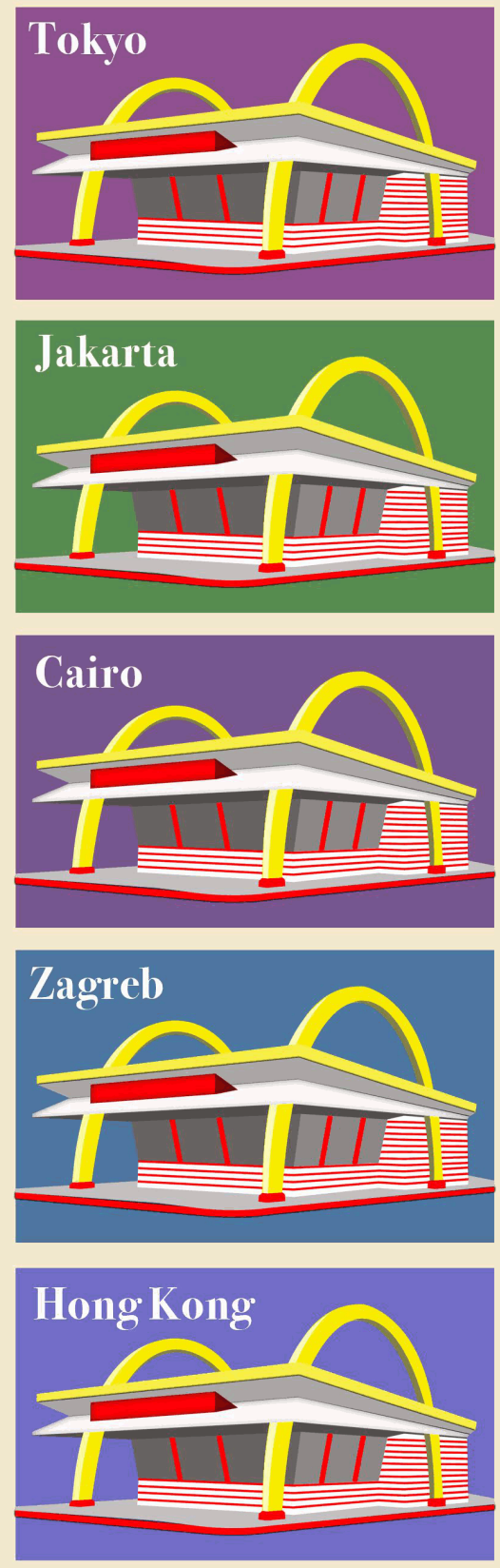

This article is available in Markets, Globalization \& Development Review: https://digitalcommons.uri.edu/mgdr/vol1/ 


\section{Marketing an End to War:}

\section{Constructive Engagement, Community}

Wellbeing, and Sustainable Peace

\section{Introduction}

One of the most important questions confronting marketing scholars, marketers, citizen-consumers and policymakers is how can markets and marketing activities be administered to serve the best interests of people justly, inclusively and sustainably? That is, how do we "make the world better, cleaner, safer, peaceful, provident, tolerant, harmonious and fairer"? (Dholakia and Atik 2016, p. 7). As marketing scholars and everyday-consumers, we know that markets and marketing emerged and became integral to societies because they in fact do have the capacity to make our lives better, safer and even more fun. They render socioeconomic systems efficient and effective, and, so far, have generally aided human survival and enhanced wellbeing. We also know that markets, marketing and the people who run them; policymakers responsible for regulating them and consumers who drive them can be irresponsible, wicked and ruthless. In some instances, they can be highly destructive to people, institutions, property and the environment. When especially harmful products are marketed, for the explicit purpose of destroying socioeconomic systems and the people thriving in them, the consequences can be devastating.

For the better part of the last 25 years, I have immersed myself in countries, regions and communities crippled by extreme conflict - places devastated by war, genocide and other forms of systemic violence sometimes during the actual fighting and destruction, sometimes during periods of recovery. In such environments, one can see the very worst of markets, marketing, marketers, consumer-behavior and policy. Among the lowlights: the annihilation of reasonably well-functioning marketing systems vital to individual quality-of-life (QOL) and societal wellbeing; the design, production, distribution, sale and application of heinous weapons and munitions; cynical manipulation by politicians and various other, supposedly moral, authorities; brutal and unconscionable profiteering and exploitation; streams of refugees, internally displaced persons (IDP) and other desperate survivors ravaged and/or raped; the remains of those who did not survive. These conditions also elicit the best from people, markets and marketing: courage, cooperation and personal sacrifice for the greater good; improvised one-off and systemic mechanisms for exchange and 
mutual benefit; organized and integrated prosocial relief-efforts, locally and globally; the emergence of nascent markets and marketing activities to deliver goods and services that assuage suffering and hint at the promise of what might possibly emerge from the ashes of obliteration. Indeed, what becomes obvious, early on, is just how indispensable welladministered marketing systems are to healthy, safe, and flourishing communities, locally, regionally and globally.

The objective of this article is to share some reflections, considerations and applications from a stream of research on warravaged, devastated, recovering and/or transitioning economies; places in which marketing systems were eradicated, fractured, or disrupted, and then emerged or re-emerged following tacit or actual peace accords or other policy changes. Some underlying facts and factors regarding war will be introduced; a thoughtful, systemic and expansive definition of marketing is revisited; an evolving model is shared to make key points about the systemic and interdependent nature of markets, peace and prosperity, including some goals of development; we will consider factors that facilitate the health, wellbeing, equity and sustainability of communities and the marketing systems that enable them and their stakeholders to flourish; we will conclude with some considerations for further research and constructive engagement toward community wellbeing, and sustainable peace and prosperity.

\section{War and Its Costs}

At the time of this writing, 40 countries are enmeshed in some form of war or military conflict. Almost all other countries, while generally peaceful to varying degrees - Denmark, Iceland and New Zealand earn especially high marks on the Global Peace Index - invest in those conflicts or peace-making via materiel, training and/or other support (Institute for Economics and Peace 2016; see also Melander, Pettersson and Themnér 2016). The costs in blood and treasure are almost impossible to comprehend.

Last year, approximately 167,00 people were killed in these wars; one third of those deaths occurred in the Syrian War, and Syria may have suffered the deaths of nearly 500,000 people since the fighting there began (Barnard 2016). Estimates for the total war-dead from the Iraq War instigated in 2003 vary widely; a credible assessment suggests the number of deaths in that country from war and related violence and lawlessness is more than 450,000 people (Hagopian et al. 2013). Higher estimates have been published, but have come under criticism for methodological shortcomings (e.g., Spagat and Dougherty 2010). Even a 
tenth of the number reported by Hagopian et al. (2013) though is a horrific body-count emblematic of profound individual, familial and societal loss and suffering.

More than 65 million people now are refugees or IDP from various wars; approximately 12.4 million were forcibly displaced due to war and persecution in 2015 alone (International Institute for Strategic Studies 2016; UNHCR 2015). Millions of others try to scratch-out existences in war-ravaged economies and disintegrated marketing systems. Billions more rely on marketing systems compromised by wars elsewhere or the threat of war in their countries.

A recent financial tally for the Iraq War is estimated to be over four trillion - yes, trillion - US dollars (Stiglitz 2015; see also Bilmes 2013). The upshot of these wars over the last 10 years: the world has become a less peaceful place, and costlier on numerous measures and when viewed through compassionate lenses.

These numbers do not alert us to the costs associated with other forms of non-military violence - criminal activity such as robberies, trafficking and rape; racketeering, gangsterism, and their brutal enforcement, to name a few examples - which perhaps occur because such large sums of money are allocated to the preparation and execution of war rather than to individual and societal wellness. The Institute for Economics and Peace (2016) has calculated that the global economic impact of violence in 2015 was $\$ 13.6$ trillion (again, trillion). To put that figure in perspective, it is equivalent to $13.3 \%$ of world GDP or five dollars per day for every person on the planet. If world violence decreased by $10 \%$, the cost savings, that is, $\$ 1.3$ trillion, would be equivalent to more than total global foreign direct investment, in 2014; ten times the amount of official development assistance in 2014 and the value of global food exports in 2014 (Institute for Economics and Peace 2016, p. 42).

The statistics should cause us to wonder about opportunity costs to education, health care, infrastructure, alternative energy, and ultimately to security, happiness and QOL. They should motivate us to ponder our fundamental decency, moral obligations, financial allocations, and of course, the markets and marketing that contribute to war and its costs.

Alternative perspectives regarding various counts, costs and benefits from military expenditures and war do exit. The number of wardeaths from 1945 to 2000 generally trended sharply downward, in actual numbers, although the death-count spiked upward after the new millennium. In one especially comprehensive analysis, Roser (2016) found the number of deaths attributed to war also has generally trended downward both in terms of total deaths and deaths per capita, annually, 
over the last 600 years. Some conflagrations, however — the Thirty Years War, Wars of Spanish Succession and of course two World Wars - were especially catastrophic, collectively causing tens of millions of deaths and ghastly privation and suffering for an even larger number of survivors. Moreover, some observers (e.g., various politicians, arms merchants, voters, professional soldiers and sailors, guerillas and terrorists) might and often do posit counterarguments that, irrespective of the costs and human suffering revealed above, the human condition would be even worse, if not for expenditures on materiel, militaries, militias, insurgencies, counterinsurgencies and full-on war. Stated differently, the production, marketing and application of resources to prepare for and to execute war - the global arms-race and military industrial complexes that lead to innovation and employment, and which protect societies from hostile activities inflicted or potentially inflicted by people, groups and states outside one's region, country or alliances - are vital to the survival of human civilization, or at least to people, groups and countries deemed to be exceptional and thus worth protecting at considerable costs to others and, ironically and even tragically, to those well-armed and even "victorious" in combat.

To be sure, the world can be dangerous. People and prosocial institutions must be protected and defended when violently attacked. The ability to protect and to defend presupposes personnel, materiel and training, and goods, services, money, markets and marketing to meet the needs of those people and institutions legitimately charged to administer their roles. However, two Ps we might be well-advised to add to the marketing mix could include: Prudence and Proportionality, manifested in larger allocations for goods and services that can positively affect individual health, wellness and QOL, and sustainable peace, prosperity and societal wellbeing. Consider again the trillions of dollars and how that sum of money otherwise might have been spent. Truly, the quest for individual safety, security, happiness and QOL, generally; the goal of societal and global peace, prosperity and wellbeing are so desirable and compelling, one wonders why those outcomes are so elusive; why human history is often a narrative of war rather than peace? There are perhaps as many answers to that question as there are people, but I draw attention to some compelling considerations, below.

\section{Conflict, Social Traps and Crimes of Omission}

How did we get ourselves into this mess, which is an existential threat to all of us? History tells us that ignorance, arrogance, hubris and greed certainly have been vanguards of this destructive process (Tuchman 
1985), but the obvious or perhaps not-so-obvious answer is that various players - policymakers, industrialists, financiers, clergy, workers, marketers and consumer-citizen/stakeholders - permitted social conflict(s) to spiral toward wide-scale, systemic and institutionalized ostracism, dehumanization and violence. Analyzed more scientifically, social conflict occurs when two or more parties pursue interests that said parties consider to be mutually interdependent and incompatible; a zerosum game whereby one or more parties achieve goals at the expense of one or more other parties (Deutsch 1973). Social conflicts moreover can be complex, and expand great stretches of time and space; they can be local and/or global, with interacting and interdependent actions by many people and institutions, with implications literally for everyone (e.g., Barrios et al. 2016; Deutsch 2006; Marcus 2006; Osgood 1962; Ostrom et al. 2002; Shultz 2015a). When stakes are especially high, when the conflict seems intractable and/or losses are calculated to be especially damaging or even an existential threat, social conflict often becomes violent and prolonged (e.g., Coleman 2014). When conflicts are systemic, institutional and politicized; when massive amounts of resources are mobilized with the intent to break the will of or to destroy an adversary in the form of a large community, nation or state; then violence can escalate to war, a condition once described as the continuation of policy - political commerce - by other means (von Clausewitz 1832/1918). When viewed from the vantage point of macromarketing and development scholars, war is policy and action that can result from perceived or real failures of, or threats to, marketing systems; that is, the political and socioeconomic organization and networks of goods, services, and experiences and institutions intended to provide and to sustain security, safety, happiness and wellbeing (e.g., Fisk 1967; Layton 2009; Shultz et al. 2005).

Typical objectives of warring parties or states are to control, disrupt or to destroy the adversary's marketing system. Combatants attempt (1) to force citizen-consumers, parties and/or states to capitulate or they attempt to eradicate the adversary, entirely; (2) to secure or to enhance the victor's marketing system at the expense of the vanquished. As suggested previously, important caveats include costs and long-term outcomes, both expected and unexpected, even to victors. Costs can be so high trillions of US dollars, hundreds of thousands to millions of deaths, millions of refugees, nearly incalculable opportunity costs - as to render victory "pyrrhic," a modifier derived from Pyrrhus, King of Epirus, who sustained such heavy losses in defeating the Romans he is reported to have said, "If we are victorious in one more battle ... we shall be utterly ruined" (in Plutarch $\left.\sim 2^{\text {nd }} \mathrm{CAD} / 1920\right)$. Consider too that vanquished nations and 
states also can recover and (re)build prosperous and benevolent marketing systems; they also can rise as tyrannical, perpetually warring states. Both scenarios suggest opportunities to affect peace before, during and after war; indeed, peace-making is a perpetual opportunity for the prudent marketer or policy-maker.

While there are many causes of the types of conflict that can escalate to war, perhaps the most insidious is a phenomenon known as the social dilemma or social trap, a condition in which people, companies, organizations and/or governments engage in seemingly rational behavior for short-term gain, but at eventual long-term and potentially devastating detriment to a larger group (e.g., Dawes 1980; Lange et al. 2014; Messick and Brewer 1983; Ostrom et al. 2002; Shultz and Holbrook 1997). Classic examples include over-harvesting pastureland, forests, fisheries or mineral deposits; essentially, degrading or entirely consuming commonly shared resources to considerable harm of future users (e.g., Hardin 1968; Lloyd 1833). Such social traps or commons dilemmas have haunted humanity for millennia (cf. Aristotle $\sim 4^{\text {th }} \mathrm{CBC} / 1976$ ), revealing their treacherous and intractable nature. Contemporary examples of global proportions, often connected to the previously indicated resource exploitation: pollution; trafficking (people, illicit drugs, weapons, nuclear material); illiteracy, poverty and poor health care; exponential population growth; bogus historical narratives and religious interpretations; cynical cartels and malevolent alliances; corruption and poor/despotic governance; the military industrial complex, arms proliferation, violence, and war. In sum, incentives for short-term personal and systemic gain often cause us to consume too much, to exploit or neglect others, even to destroy humanbeings, their habitats, vestiges of their culture, entire civilizations - at massive, existentially threatening costs to Homo Sapiens and the finite, perishable planet we inhabit (Shultz 2015a).

Some of these global traps and trends interact; they all are replete with dilemmas for marketing practitioners, consumers and policymakers; they all are, or should be, of interest to marketing scholars committed to understanding and affecting safe, peaceful and sustainable markets, globalization and development. Ironically - embarrassingly or shamefully from the perspective of Macromarketers, members of the International Society of Markets and Development (ISMD), and other thoughtful scholars - markets and marketing contribute greatly to social traps, as we recklessly design, produce, promote, distribute, consume and dispose all manner of goods and services that wreak havoc on our communities, countries and planet (Shultz and Holbrook 1997). Marketers have promoted a consumer culture that is probably found in some form, in every 
country and society. If one were to find a place in which no remnants of consumer culture are found, that location nevertheless is still affected by a global consumer culture. Markets and marketing therefore are frequently and visibly castigated for their roles in creating and perpetuating social traps, if not by aim then by outcomes, and the damage they cause; some critics go so far as to conclude the cause rests squarely on the proverbial shoulders of marketing; that marketing is a form of destructive engagement. This charge is partly fair, but not particularly useful, as we shall see below.

Compounding the myriad problems of social traps are willful decisions not to engage them and thus to perpetuate their extant and long-term harm. Consistent with the Acts and Omissions Doctrine, such decision-making is often considered to be a crime-of-omission, essentially choosing not to engage constructively in situations or systems when one can reasonably expect, due to that choice, a harmful result occurs (e.g., Oxford Dictionary of Philosophy 2008; see also Mill 1859 and thoughts on the permanent interests of humankind). In other words, the "crime" might be considered a denial of or disregard for the social trap, because of a failure to intervene in ways to mitigate or to eliminate the harmful effects of it (Shultz 2015a). The fundamental tenets of the Doctrine, a form of consequentialism, are deeply rooted in both western and eastern philosophies. Cicero (44 BC/2010), for example, wrote eloquently of "passive injustice". Some four centuries earlier, Mo Tzu, one of China's great moral and political philosophers, argued that governments must help to manage resources for the greater good; Mohist consequentialism was an early, systemically wide effort to interact benevolently with others, particularly smaller and more vulnerable states and their citizens, while reducing or eliminating harm. Note too that Mo Tzu condemned war and favored what might be considered constructive engagement with distant states to prevent it (Ivanhoe and Van Norden 2005, p. 60; Shultz 2015a, p. 196).

Two millennia later, we find ourselves mired in global, violent conflict and reckless devastation of human and physical resources; a vicious cycle of unsustainable consumption, resource destruction and war, which some would argue is increasingly perpetuated by markets and marketing. Moreover, we live in a time in which government policy including war -is shaped by corporations, their global brands, and the consumers who crave them, all of which begs questions concerning the extent to which such interaction and engagement is constructive, particularly in the context of commons-preservation, and sustainable peace, prosperity and wellbeing. Specifically, can marketing be a vital 
force for constructive engagement to affect positively the human condition, peacefully and sustainably?

\section{Marketing as Constructive Engagement}

Markets and marketing emerged because, more-often-than-not, they enhanced the safety, wellbeing and survivability of individual humans, entire societies and the environments in which they thrived; so well in fact, the story of human civilization has been scripted and greatly defined by marketing and consumption, and the marketing systems in which we thrive (e.g., McMillan 2003; Shultz 2015a). We truly are Homo Marketus (Shultz 2007). Even in the most draconian non-marketing systems such as prisons and authoritarian command-economies, humans find ways to engage in mutually beneficial exchange via black or illicit markets to survive, if not necessarily to thrive. Thus, rather than to embark on some fool's errand to eliminate markets and marketing, it is incumbent upon policy-makers, marketers, consumers and marketing scholars to ameliorate social traps, to overcome crimes-of-omission and to develop markets, marketing-systems and consumer opportunities in large-scale, interdependent problem-solving situations with intentions to improve the human condition and to affect social justice. That said, and as mentioned elsewhere, short-sightedness and/or misguided incentive structures in marketing systems deliberately or obliviously often result in destructive policies and practices. Consequently, the contemporary conceptualization of marketing and the dynamics of marketing systems must be explored to understand the players and the effects of their marketing activities on current and future stakeholders. Better comprehension of marketing systems and repercussions of their (mis)management can facilitate ethical, pro-social and sustainable policies and behaviors to help us to ameliorate or ideally to eliminate the most dangerous social traps, such as war (e.g., Shultz 2015a; see also Layton 2015).

Toward that outcome, we must revisit marketing as a form of constructive engagement - a societal function and a systemic set of processes for creating, communicating, and delivering goods, services and experiences to consumers and for managing consumer, societal and political relationships in ways that benefit local, regional and global stakeholders of these processes, justly and sustainably (see also Shultz 2007, p. 293). This definition, or some expanded form of it, derives from earlier, more historical (e.g., McMillan 2003), macromarketing (e.g., Alderson 1957, Fisk 1981; Wilkie and Moore 1999), and holisticdevelopment perspectives (e.g., Dholakia and Atik 2006; Kumcu and Firat 1988) rather than considerations and actions evinced in the more micro- 
and managerially-focused paradigm prevalent today. Although, as shall be seen below, in a global marketing system, the multiple perspectives macro and micro, powerful and less powerful, wealthy and poor - are very much interdependent and affect both the global and local (see also Firat 2016).

Figure 1 in the following text is potentially helpful to make key points regarding destructive and constructive engagement in a conflicted glocal economy that often devolves into war. Its conceptualization, structure and elements emerged from an analysis of Southeast Asia's transitioning economies (Shultz and Pecotich 1997), a prescription for management of California's redwood forests (Shultz and Holbrook 1999), and exploration of constructive engagement between Vietnam and the United States (Shultz 2007).

\section{Figure 1: Schema Contrasting Destructive and Constructive Engagement in a Conflicted Glocal Economy.}

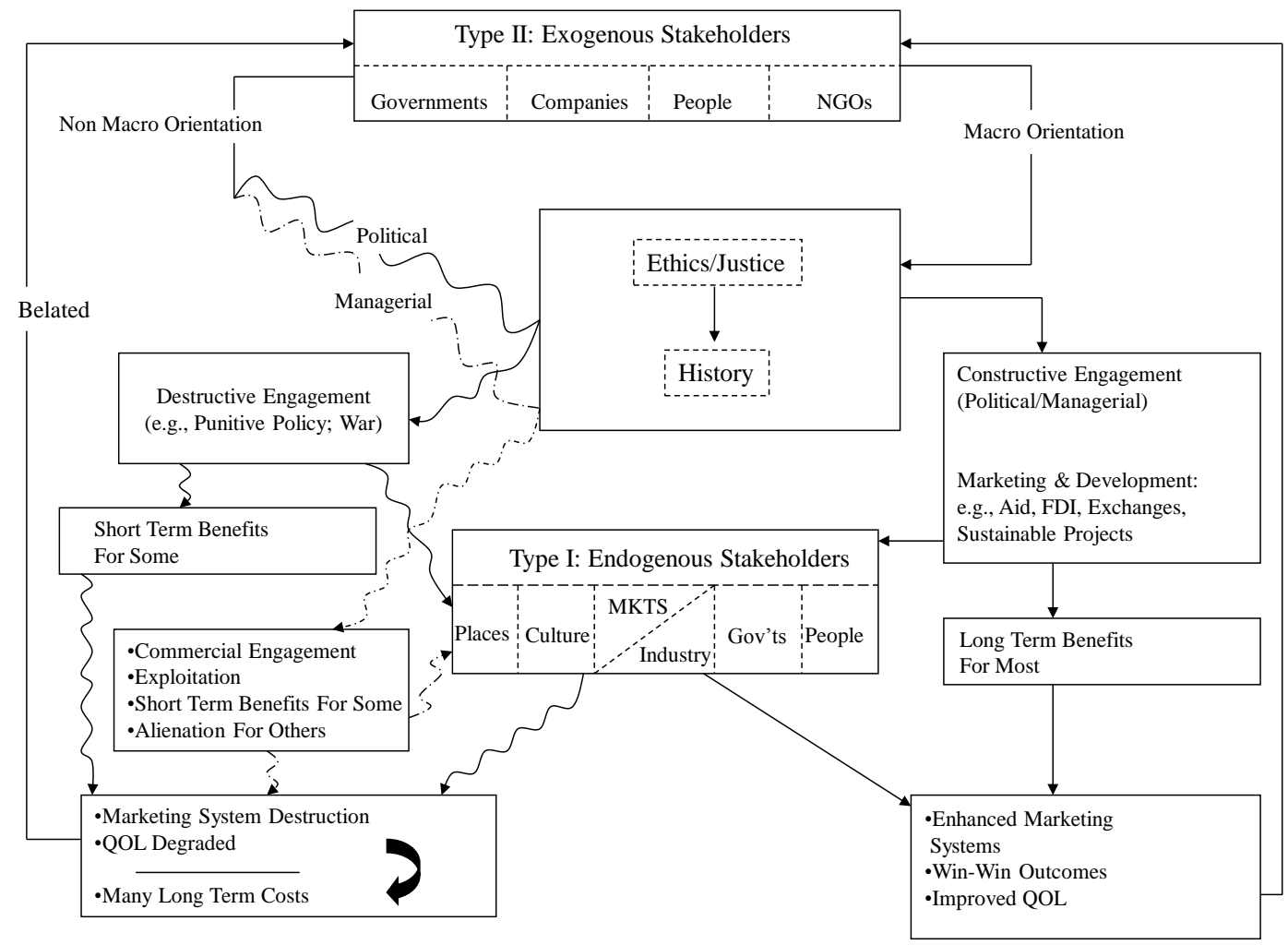

Source: Shultz (2015a, p. 204); cf. Shultz (2007, p. 296). 
The particular model shown here is from a recent assessment of the greater Mekong basin vis-à-vis interdependent local and global glocal - stakeholders (Shultz 2015a, p. 204), which draws on the voluminous literature in social psychology, conflict resolution and cooperation, principally in the context of social dilemmas and traps (e.g., Coleman et al. 2014; Deutsch 1973; Dawes 1980; Messick and Brewer 1983; Ostrom et al. 2002; Lange et al. 2014), as well as previously cited works on prosocial marketing and consumer behavior. A synthesis of that literature suggests that social traps are best mitigated, managed or prevented by regulations, positive incentives and penalties, organization, cooperation, communication, and many tools well understood by marketers that can complement other processes and initiatives (e.g., Shultz 2015a). When the social trap results in or becomes war, or other forms of systemically violent and politicized conflict in which multiple systems have fractured, and have become corrupted and criminalized, constructive engagement and peacemaking can foster predictable, transparent and enforceable rules, empowerment of the vulnerable and disenfranchised, communication among stakeholders, and community building at multiple levels (Barrios et al. 2016).

At the heart of the model is appreciation for the historical realities and accordant sensitivities and respect required for constructive engagement, and a concern that no engagement can be truly constructive if it does not include ethical decision-making and result in social justice (see also Santos and Laczniak 2011). Note also that the Endogenous Stakeholders are designated Type I, suggesting that people's QOL and sustainable wellbeing of the society and its assets with whom the Exogenous Stakeholders are engaging are priority outcomes for development. The model also reveals the temptations to engage destructively via Non Macro Orientation, a more micromarketing approach concerned only with immediate cost-savings and short-term profits. This is a classic strategy and social trap in developing markets. Rapacious extraction or harvesting, unconscionable working conditions, pollution, and/or aggressive and poorly conceived/administered military intervention often accompany engagement and "development" by some Exogenous Stakeholders. Despite short-term gain for some, however, the costs are many and long-lasting, and almost inevitably require some change to engagement/development policy to affect more just and sustainable outcomes. Alternatively, constructive engagement in the form of a Macro Orientation emphasizes systemic actions and implications, ethical decision-making and social justice, sustainable policies and business practices, multi-win outcomes for as many people as possible, especially 
when those goals pertain to enhanced individual QOL and societal wellbeing. The Macro Orientation furthermore champions stakeholder inclusion, agreed-upon and measurable outcomes and timelines, transparency, and recourses if agreements are not met, and therefore do not enhance QOL or contribute to flourishing communities, states and regions.

\section{Development toward Flourishing Communities, QOL, and Sustainable Wellbeing}

Readers will have noticed a consistent refrain to focus on QOL and wellbeing as desirable outcomes from marketing and development. Outcomes no reasonable person or government would oppose, one would think. Toward those goals, constructive engagement as articulated above offers a responsible macromarketing orientation for geo-political-marketing interactions and even smaller scale interactions when systemic complexities, power differentials, consumer vulnerabilities and high probability for violent interactions exist (see also Coleman 2014; Forcese 2002). Specific factors to consider in this process are less clear and are open to debate, as are the units of analysis. Indeed, measures, indices and interpretations of those constructs vary widely and often are culturally antagonistic and/or politically charged. The United Nations (UN) provides one example of a useful, but controversial and imperfect measure, the long-standing Human Development Index (UDNP 2016; cf. Wolff, Chong and Auffhammer 2011). More conceptually, the UN (2016a) has ushered in 17 new initiatives for its development goals, with year 2030 the targeted actualization-date, though not without dissent and compromise. Goal 16 incidentally is intended to promote peaceful, inclusive, just and sustainable societies, and institutions responsible for them (UN 2016b; see also World Bank 2016, p. 55). The World Bank (2016) has over 1300 measures for development, and the Community Indicators Consortium (2016) lists over 350 assessment projects, indices and data-bases for community wellbeing. Despite the depth and breadth of these and other concepts and metrics, calls for still more holistic/inclusive/representative/just/expansive/accurate measures or interpretations are common. These realities remind us the world is comprised of (1) myriad and conflicting values of innumerable stakeholders and that (2) all measures have limitations (Shultz 1997).

Fresh and evolving perspectives have been offered by the ISMD for nearly 30 years (e.g., Dholakia 2016; Polsa et al. 2016); an eclectic mix of scholars committed to QOL research is making important contributions in this space as well (e.g., Hagerty et al. 2001; Peterson 2006; Sirgy et al. 
2006). Bridging both communities, Shultz, Rahtz and Sirgy (in press) share a synthesis from several disciplines suggesting that individual QOL and societal wellbeing are most likely to be enhanced when several factors are considered and, when possible, managed. In so doing, communities can transition from distressed to flourishing; from devastated and recovering to peaceful, prosperous and sustainable. Similarly to Firat (2016, p. 12), the focus is on "community," not only in the sense of a scholarly community engaged in marketing and development research, but the conceptualization of community, and levels of analysis and engagement in devastated and/or developing markets, over time. That is, development should systemically and temporally focus on communities of shared interests and values; of various sizes, shapes and organization, some of which intersect and overlap, locally and globally. These ideas build on foundations from conflict-resolution research (e.g., Coleman et al. 2014; Lewin ([1948] 1997], macromarketing and development literature (e.g., Alderson 1956; Slater 1968), economics (e.g., Sen 1999) and seminal contributions by the Marketing and Development community (e.g., Firat and Kumcu 1988), as well as evolving models from the author's own research to explain and to assist transitioning and recovering economies seeking to develop and to thrive under new socioeconomic protocols and transforming governance (e.g., Shultz 1997; Shultz et al. 2005; Shultz et al. 2012; Shultz and Pecotich 1997).

With respect to metric imperfections and multiple and often conflicting perspectives, the framework by Shultz, Rahtz and Sirgy (in press) lists and articulates spatially-integrated factors that inevitably are important to the process of sustainable and equitable development, and peace and prosperity. The framework is intended to be tolerant and accommodating to variances in specific measures and indices. QOL and community wellbeing, not surprisingly are the targeted goals. Goalachievement in devastated, recovering, transitioning and/or developing economies requires various goods and services, in appropriate assortment, amount, quality and choice; and in response to idiosyncratic needs of the focal community and realities (challenges or opportunities) presented by Macro Factors. Macro Factors include geographical forces and the physical environment; population (e.g., size, density, hetero/homogeneity); political, economic, legal, administrative models of governance; social/cultural forces; education (institutions and models), infrastructure (physical and/or technological). Potential determinants of the needs of the community's citizen-consumers include their location/access, income/wealth/capital, situational commonalities, motivation, market literacy, and individual health/wellness (see also Shultz 2015b). The 
responsibility to orchestrate or to ensure the creation of goods and services, best practices to deliver them - while attending to Macro realities and Community/Citizen needs - rests with catalytic institutions (endogenous/exogenous, local/global): Governments, Businesses, NonGovernmental Organizations (NGOs).

The importance of these catalytic institutions, and what their cooperation and coordination make possible, cannot be overstated. The more cooperative and goal-oriented they are, the more they can form appropriate macro-micro linkages. Such linkages are particularly useful when they appear as best-practices to mitigate social dilemmas and to prevent conflict or redirect conflict into prosocial marketing activities, including entrepreneurship and related education, training and employment; micro and small-to-medium-sized enterprises; social enterprises, and larger private-sector and public-sector initiatives that collectively can create and deliver an assortment of useful goods, services and experiences; societal predictability; and citizen-consumer trust, confidence and cooperation. A marketing system accordingly can transition from devastated or developing to recovered and developed, and in turn can achieve the goals of sustainable and equitable Individual QOL and Community Wellbeing. Additionally, the more communities and marketing systems are interconnected, interdependent and cooperative in their shared humanity - locally and globally - the more likely we are to live in a prosperous, peaceful and sustainable global community.

\section{Summary and Considerations for Further Research}

Markets and marketing are ubiquitous; they have been - and will continue to be - integral to human civilization. While they are intended to enhance the human condition, they often do so in ways that can result in benefits for some and profound disenfranchisement and destructive outcomes for others. Marketing activities associated with war are clearly devastating to some of us and potentially to all of us. We must be cognizant of social traps inherent to some marketing and consumer behaviors, and to willful failure to engage constructively those traps that can spiral to extreme social conflict, violence and war. A Macro-oriented approach - marketing as constructive engagement - can prevent, ameliorate or cease social traps, including seemingly intractable violent conflict, and can facilitate systemic win-win outcomes, community building and sustainable peace. Specific factors in marketing systems can be assessed and changed to enhance development; that is, to transform communities - large, small and interconnected - from devastated/distressed to sustainably flourishing. Thoughtful inclusion of 
stakeholders of these systems and communities will help to foment cooperation and to coordinate markets, marketing, policy, consumption, and marketing-and-development research as drivers or facilitators of individual QOL, community wellbeing, and sustainable peace and prosperity.

In this process, we should explore the evolving conceptualization, boundaries, reach and fluidity of "communities", which typically are distinguished by shared and common interests. Boundaries may be set, for example, by geography; religious, cultural and/or tribal affinities; marketing-reach, and consumer preferences and patterns; governments; political parties, professions, clubs and other chosen memberships; gender or sexual orientation; socioeconomic status; military, para-military or guerilla control and conquest. The interactions of globalization, markets, marketing, violent conflict and/or war may cause boundaries to ossify, to shrink, to expand, to blur, or perhaps to disappear with implications for markets, marketing, consumer-behavior, policy, conflict and its resolution, development, and building flourishing communities.

Some of the text shared here hopefully will inspire scholars interested in marketing, policy and development to channel some of their research energy and skills to consider and perhaps to engage issues and institutions germane to the topic of conflict, including violent social conflict and especially war, and more importantly to offer constructive market, marketing, policy and consumer-behavior solutions to them. While we remain hopeful for peace, history and current events suggest marketing scholars, practitioners, policymakers and consumer-citizens from various and intersecting communities must cooperate and constructively engage each other, and the many challenges and opportunities in this space, if we are to ensure that markets and marketing will be administered to serve the best interests of all people - justly, inclusively and sustainably. 


\section{References}

Alderson, Wroe (1956), Meeting the Russians, Philadelphia, PA: American Friends Service Committee.

Alderson, Wroe (1957), Marketing Behavior and Executive Action, a Functionalist Approach to Marketing, Richard D. Irwin, Homewood, III.

Aristotle ( $\sim 4^{\text {th }}$ CBC, 1976), The Politics of Aristotle, Books I-V. trans. Franz Susemihl and Robert Drew Hick, New York: Arno Press.

Barnard, Anne (2016), "Death Toll From War in Syria Now 470,000, Group Finds," The New York Times, (accessed October 10, 2016), [available

at http://www.nytimes.com/2016/02/12/world/middleeast/death-tollfrom-war-in-syria-now-470000-group-finds.html].

Barrios, Andres, Kristine de Valck, Clifford Shultz, Olivier Sibai, Katharina Husemann, Matthew Maxwell-Smith and Marius Luedicke (2016), "Marketing as a Means to Transformative Social Conflict Resolution: Lessons from Transitioning War Economies and the Colombian Coffee Marketing System," Journal of Public Policy \& Marketing, 35 (2), 185-197.

Bilmes, Linda (2013), "The Financial Legacy of Iraq and Afghanistan: How Wartime Spending Decisions Will Constrain Future National Security Budgets." HKS Faculty Research Working Paper Series RWP13-006, March 2013, Harvard University: Cambridge, MA.

Coleman, Peter (2014), "Intractable Conflict," in The Handbook of Conflict Resolution: Theory and Practice, 3rd ed. P. Coleman, M. Deutsch, and E. Marcus, eds. San Francisco: Jossey-Bass, 708-743.

Coleman, Peter, Morton Deutsch and Eric Marcus, eds. (2014), Handbook of Conflict Resolution: Theory and Practice. San Francisco: JosseyBass.

Community Indicators Consortium (2016), Indicator Projects, Issaquah, WA: Community Indicators Consortium, (accessed October 19, 2016), [available at http://www.communityindicators.net/projects].

Dawes, Robyn M. (1980), "Social Dilemmas," Annual Review of Psychology, 31, 169-193.

Deutsch, Morton (1973), The Resolution of Conflict: Constructive and Destructive Processes. New Haven, CT: Yale University Press. 
Deutsch, Morton (2006), "Cooperation and Competition," in The Handbook of Conflict Resolution: Theory and Practice, M. Deutsch, P. Coleman, and E. Marcus, eds. Hoboken, NJ: Wiley, 23-42.

Dholakia, Ruby (2016), "ISMD: Glimpses in the Rearview Mirror," Markets, Globalization \& Development Review, 1 (1), Article 2.

Dholakia, Nikhilesh and Deniz Atik (2016), "Markets, Globalization, Development: Charting the Intersections of Three Multipolar Concepts," Markets, Globalization \& Development Review, 1 (1), Article 1.

The Economist (2015), "A Tale of Three Countries," Special Report: Colombia, (accessed October 31, 2015), [available at http://www.economist.com/news/special-report/21676959-securityand-developmentare-crucial-achieving-peace-ground-tale-three].

Firat, A. Fuat (2016), "The Dynamics of the Local and the Global: Implications for Marketing and Development," Markets, Globalization \& Development Review, 1(1), Article 4.

Fisk, George (1967), Marketing Systems: An Introductory Analysis. New York: Harper and Row.

Fisk, George (1981), "An Invitation to Participate in Affairs of the Journal of Macromarketing," Journal of Macromarketing, 1 (1), 3-6.

Forcese, Craig (2002), "Globalizing Decency: Responsible Engagement in an Era of Economic Decency," Yale Human Rights Law Journal, 5, $1-55$.

Hagerty, Michael, Robert A. Cummins, Abbott L. Ferriss, Kenneth Land, Alex C. Michalos, Mark Peterson, Andrew Sharpe, M. Joseph Sirgy, and Joachim Vogel (2001), "Quality of Life Indexes for National Policy: Review and Agenda for Research," Social Indicators Research, 55, 1-96.

Hagopian, Amy, Abraham D. Flaxman, Tim K. Takaro, Sahar A. Esa Al Shatari, Julie Rajaratnam, Stan Becker, Alison Levin-Rector, Lindsay Galway, Berq J. Hadi Al-Yasseri, William M. Weiss, Christopher J. Murray, Gilbert Burnham (2013), "Mortality in Iraq Associated with the 2003-2011 War and Occupation: Findings from a National Cluster Sample Survey by the University Collaborative Iraq Mortality Study," PLOS Medicine, 10 (10), (accessed October 15 , 2016), 
http://journals.plos.org/plosmedicine/article/asset?id=10.1371/journ al.pmed.1001533.PDF].

Hardin, Garrett (1968), "The Tragedy of the Commons," Science, 162, 1243-1248.

Institute for Economics and Peace (2016), Global Peace Index 2016, Sydney: Institute for Economics and Peace.

International Institute for Strategic Studies (2016), Armed Conflict Database, London: International Institute for Strategic Studies, (accessed October 17, 2016), [available at https://acd.iiss.org/].

Ivanhoe, Philip J. and Bryan Van Norden (2005), Readings in Classical Chinese Philosophy. Cambridge, MA: Hackett Publishing.

Kumcu, Erdogan and A. Firat Fuat, eds. (1988), Marketing and Development: Toward Broader Dimensions. Greenwich, CT: JAI Press.

Layton, Roger A. (2009), "On Economic Growth, Marketing Systems, and the Quality of Life," Journal of Macromarketing, 29 (4), 349-62.

Layton, Roger A. (2015), "Formation, Growth, and Adaptive Change in Marketing Systems," Journal of Macromarketing, 35 (3), 302-319.

Lewin, Kurt ([1948] 1997), Resolving Social Conflicts and Field Theory in Social Science, G.W. Lewin, ed. Washington, DC: American Psychological Association.

Lloyd, William F. (1833), Two Lectures on the Checks to Population. Oxford: Oxford University Press.

Mason, Simon A. and Adrian Muller (2004), "Analyzing Economic Market Interactions as Conflicts: New Concepts to Assess Market-Based Policy Instruments," Ecological Economics, 61 (1), 81-90.

McMillan, John (2003), Reinventing the Bazaar: The Natural History of Markets. New York: Norton.

Melander, Erik, Therese Pettersson, and Lotta Themnér (2016), "Organized Violence, 1989-2015," Journal of Peace Research, 53 (5), 727-742.

Mill, John Stuart (1859), On Liberty. London: John W. Parker and Son.

Osgood, Charles E. (1962), An Alternative to War or Surrender. Urbana, IL: University of Illinois Press. 
Ostrom, Elinor, Thomas Dietz, Nives Dolšak, Paul C. Stern, Susan Stonich, and Elke U. Weber, eds. (2002), The Drama of the Commons. Washington, DC: National Academy Press.

Oxford Dictionary of Philosophy (2008), "Acts/Omissions Doctrine," Oxford: Oxford University Press, (accessed June 5, 2016), [available at http://www.oxfordreference.com/].

Peterson, Mark (2006), "Identifying Quality-of-Life Priorities for Societal Development: Using a Market Orientation to Benefit Citizens," Journal of Macromarketing, 26 (1), 45-58.

Plutarch ( $\left.2^{\text {nd }} \mathrm{CBC} / 1920\right)$, "The Life of Pyrrhus," The Parallel Lives, Vol. IX, trans. Perrin, B., Loeb Classical Libraries, (accessed September 24, 2016), [available at http://penelope.uchicago.edu/Thayer/e/roman/texts/plutarch/lives/p yrrhus*.html].

Polsa, Pia, Janice Denegri-Knott, Rosario Mellado-Silva and Finola Kerrigan, eds. (2016), Challenging Development and Markets: Proceedings of the $14^{\text {th }}$ Biennial Conference of the International Society of Marketing and Development, Lima, Peru: ISMD \& Universidad del Pacífico.

Roser, Max (2016), "War and Peace over the Long Run," (accessed October 17, 2016), [available at https://ourworldindata.org/war-andpeace-long-run].

Santos, Nicholas and Gene Laczniak (2011), "Marketing to the Poor: An Integrative Justice Model for Engaging Impoverished Market Segments," Journal of Public Policy \& Marketing, 28 (1), 3-15.

Sen, Amartya (1999), Development as Freedom. New York: Oxford University Press.

Shultz, Clifford (1997), "Improving Life Quality for the Destitute: Contributions from Multiple-Method Fieldwork in War-Ravaged Transition Economies," Journal of Macromarketing, 17 (1), 56-67.

Shultz, Clifford (2007), "Marketing as Constructive Engagement," Journal of Public Policy \& Marketing, 26 (2), 293-301.

Shultz, Clifford (2015a), "The Ethical Imperative of Constructive Engagement in a World Confounded by the Commons Dilemma, Social Traps, and Geopolitical Conflicts," in Handbook on Ethics in Marketing, Alexander Nill, ed., Northampton, MA: Edward Elgar, 188-219. 
Shultz, Clifford (2015b), "Normative Drivers of Justice, Development, Law and National Well-being," presentation at Global Forum on Law Justice and Development, World Bank, Washington, DC (November 16).

Shultz, Clifford, Timothy Burkink, Bruno Grbac and Nataša Renko (2005), "When Policies and Marketing Systems Explode: An Assessment of Food Marketing in the War-Ravaged Balkans and Implications for Recovery, Sustainable Peace, and Prosperity," Journal of Public Policy \& Marketing, 24 (1), 24-37.

Shultz, Clifford and Morris Holbrook (1999), "Marketing and the Tragedy of the Commons: A Synthesis, Commentary, and Analysis for Action," Journal of Public Policy \& Marketing, 18 (2), 218-229.

Shultz, Clifford and Anthony Pecotich (1997), "Marketing and Development in the Transition Economies of Southeast Asia: Policy Explication, Assessment and Implications," Journal of Public Policy \& Marketing, 16 (1), 55-68.

Shultz, Clifford, Don Rahtz and M. Joseph Sirgy (in press), "Distinguishing Flourishing from Distressed Communities: Vulnerability, Resilience and a Systemic Framework to Facilitate Well-Being," in The Handbook of Community Well-Being, Rhonda Phillips and Cecelia Wong, eds. Dordrecht, Netherlands: Springer.

Sirgy, M. Joseph, Alex Michalos, Abbott L. Ferriss, Richard A. Easterlin, Donald Patrick and William Pavot (2006), "The Quality-of-Life (QOL) Research Movement: Past, Present, and Future," Social Indicators Research, 76, 343-466.

Spagat, Michael and Josh Dougherty (2010), "Conflict Deaths in Iraq: A Methodological Critique of the ORB Survey Estimate," Survey Research Methods, 4 (1), 3-15.

Stiglitz, Joseph (2015), "Nobel Laureate Joseph Stiglitz on 'Rewriting the Rules of the American Economy' (Part 2)," Interview with Amy Goodman, for Democracy Now, (accessed October 17, 2016), [available http://www.democracynow.org/blog/2015/10/27/nobel laureate jos eph stiglitz on rewriting.]

Tuchman, Barbara (1985), The March of Folly: From Troy to Vietnam. New York: Random House. 
UNDP (2016). Human Development Reports: Human Development Index (HDI), (accessed October 10, 2016), [available at http://hdr.undp.org/en/content/human-development-index-hdi], New York: United Nations Development Programme.

UNHCR (2015), "Global Trends: Forced Displacement in 2015," New York: United Nations, (accessed October 25, 2016), [available at http://www.unhcr.org/en-us/statistics/unhcrstats/576408cd7/unhcrglobal-trends-2015.html].

United Nations (2016a), "Sustainable Development Knowledge Platform," New York: United Nations, (accessed October 20, 2016), [available at https://sustainabledevelopment.un.org/].

United Nations (2016b), "Sustainable Development Goal 16," New York: United Nations, (accessed October 20, 2016), [available at https://sustainabledevelopment.un.org/sdg16].

von Clausewitz, Carl (1918), On War, Graham, J. J. trans., London: Kegan Paul, Trench, Trubner \& Co.

Wilkie, William and Elizabeth Moore (1999), "Marketing's Contributions to Society," Journal of Marketing, 63 (Special Issue), 198-218.

Wolff, Hendrik, Howard Chong and Maximilian Auffhammer (2011), "Classification, Detection and Consequences of Data Error: Evidence from the Human Development Index," Economic Journal, 121 (553), 843-870.

World Bank (2016), World Development Indicators 2016, Washington: World Bank Group, (accessed October 25, 2016), [available at https://issuu.com/world.bank. publications/docs/9781464806834?e= 0/35179276]. 